\section{Shock, Coma, and Electrocardiographic Change with Enzyme Release in Case of Wasp-sting Allergy}

British Medical fournal, 1969, 3, 761

Serious acute allergic reactions may present in different clinical forms. Respiratory difficulties, circulatory inadequacy, or coma are well recognized. Our patient with an allergy to wasp venom presented as a medical emergency which caused considerable diagnostic difficulty.

\section{CASE Report}

A man of 68 was stung by a wasp while he was gardening. Eighteen months previously he had been stung and had felt faint; he then lapsed into unconsciousness for about an hour. On the present occasion he collapsed suddenly without any warning after walking 100 yards (90 metres) after the sting. He was admitted to hospital three-quarters of an hour later.

On examination he was unconscious, responding only to painful stimuli. He was pale, and the pulse was 120 per minute. The blood pressure was at first unrecordable, but within a few minutes and without resuscitative measures it had risen to 120/80. He remained unconscious for about 12 hours, and for a further six hours was confused and irritable before recovering consciousness completely. He was then able to remember the sting and recollect what had happened.

Investigations.-Haemoglobin $106 \%$; E.S.R. $4 \mathrm{~mm}$. in one hour ; white cell count $12,000 / \mathrm{cu}$. mm. ( $68 \%$ polymorphs). Blood urea $32 \mathrm{mg} . / 100 \mathrm{ml}$. The results of enzyme tests performed on blood 24 hours after the sting are given in the Table. The electrocardiogram on admission (Fig. 1a) showed widespread S-T segment abnormalities; small junctional waves were also noted. Next day the record (Fig. 1b) was entirely normal. At a later date an exercise electrocardiogram was obtained, and this too was normal. Estimates of enzyme activity six months later were all within normal range (see Table).

Serum Enzyme Levels 24 Hours and Six Months After Sting

\begin{tabular}{|c|c|c|c|}
\hline Enzyme Method & Normal & 24 Hours & 6 Months \\
\hline $\begin{array}{l}\text { S.G.O.T. (i.u./1.) (Henry et al., 1960) } \\
\text { S.G.P.T. (i.u./1.) (Henry et al., 1960) } \\
\text { C.P.K. (i.u./.) (Wortley et al., 1969) } \\
\text { S.H.B.D. (i.u./1.) (Hirst and Goldberg, 1969) } \\
\text { O.C.T.(i.u./1.) (Konttinen, 1968) } \\
\text { I.C.D.H. (i.u./1.) (Wolfson et al., 1957) }\end{array}$ & $\begin{aligned}<40 \\
<30 \\
<70 \\
<200 \\
<0 \cdot 40 \\
<6\end{aligned}$ & $\begin{array}{c}292 \\
58 \\
3,680 \\
225 \\
0 \cdot 48 \\
4\end{array}$ & $\begin{array}{l}17 \\
10 \\
22 \\
115 \\
0 \cdot 38 \\
5\end{array}$ \\
\hline
\end{tabular}

S.G.O.T. $=$ Serum aspartate aminotransferase. S.G.P.T = Serum alanine aminotransferase. C.P.K. $=$ Creatinine phosphokinase. S.H.B.D. = Serum hydroxybutyrate dehydrogenase. O.C.T. = Ornithine carbamoyl transferase. I.C.D.H. = Isocitric dehydrogenase.

The patient has undergone a course of desensitizing injections without untoward events other than pain at the site of injection. Repeated enzyme estimations before and after each injection showed no abnormality.

\section{COMMENT}

Coma in acute allergic reactions may be due to cerebral damage. Cerebral vascular engorgement, focal haemorrhage, and vacuolization of white matter have been described (Barnard, 1967). In our patient the coma was prolonged for about 10 hours, but recovery was complete without residual neurological abnormality.

Acute hypotension is thought to be related to kinin histamine and 5-hydroxytryptamine release. Occasionally hypotension might be related to secondary cardiac arrhythmia (James and
Austen, 1964). In this case sinus tachycardia was presumably the response to acute hypotension.

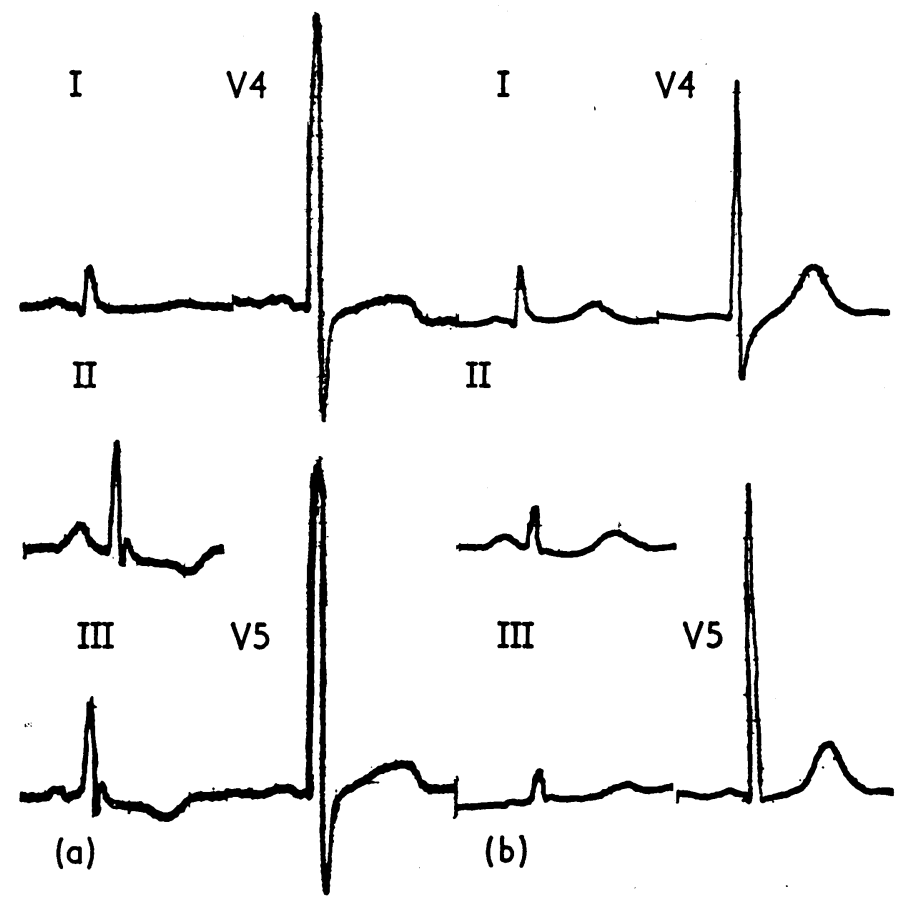

Electrocardiogram. (a) On admission, showing junctional waves and S-T segment abnormality. (b) Next day.

Electrocardiographic abnormalities in this case raised the possibility of myocardial infarction, but the rapid return to normality and the normal exercise electrocardiograms at a later date are against a diagnosis of coronary disease. $T$-wave changes were seen in the case described by Booth and Patterson (1968) and recurred in their patient when she was unwittingly exposed to the allergen for a second time. The junctional waves noted in the E.C.G. on admission were not associated with hypothermia.

The pronounced rise in serum enzyme activity was detected at a time ( 24 hours after admission) when the electrocardiogram was quite normal. As mentioned above, we do not think that there was evidence of coronary disease. Hypotension may have led to relative cardiac or skeletal muscle ischaemia with resulting enzyme release. An alternative possibility is an increase in cellular permeability due to the acute allergic process.

Our thanks are due to Dr. T. E. Gumpert for permission to describe this case and to Dr. D. M. Goldberg for helpful advice.

\section{T. J. DeEBLE, M.B., CH.B. \\ E. JACKSON, M.B., B.SC., M.R.C.P,}

Royal Hospital, Sheffield.

\section{REFERENCES}

Barnard, J. H. (1967). Fournal of Allergy, 40, 107

Booth, B. H., and Patterson, R. (1968). Fournal of Allergy, 42, 364. Henry, R. J., Chiamori, N., Golub, O. J., and Berkman, S. (1960).

Hirst, A. D., and Goldberg, D. M. (1969). British Heart fournal. In

press.
James, L. P., and Austen, K. F. (1964). New England fournal of Medicine, $270,597$.

Konttinen, A. (1968). Clinica Chimica Acta, 21, 29.
Wolfson, S. K., and Williams-Ashman, H. G. (1957). Proceedings of the Society of Experimental Biology and Medicine, 96, 231.

Worthy, E., Whitehead, P., and Goldberg, D. M. (1969). Enzymologia Biologica et Clinica. In press. 